\title{
Environmental impact of mining activity in Bor area as indicated by the distribution of heavy metals and bacterial population dynamics in sediment
}

\author{
M.N. Filimon ${ }^{1}$, R. Popescu ${ }^{2, \star}$, F.G. Horhat ${ }^{3}$ and O.S. Voia ${ }^{4}$ \\ 1 West University of Timisoara, Faculty Chemistry, Biology, Geography, Department Biology-Chemistry, Pestalozzi 16, \\ 300315 Timisoara, Romania \\ 2 University of Medicine and Pharmacy "Victor Babes", Department of Cell and Molecular Biology, E. Murgu 2 300041, Timisoara, Romania \\ 3 University of Medicine and Pharmacy "Victor Babes", Department of Microbiology, E. Murgu 2 300041, Timisoara, Romania \\ ${ }^{4}$ Banat University of Agricultural Sciences and Veterinary Medicine from Timisoara, Faculty of Animal Science and Biotechnologies, \\ Aradului Street 119, 300645, Timisoara, Romania
}

Received December 30, 2015 - Revised May 17, 2016 - Accepted May 26, 2016

\begin{abstract}
The environmental impact of inorganic pollution is pronounced in water adjacent to Bor Copper Smelter Complex (RTB Bor, Serbia), with $\mathrm{Cu}, \mathrm{Zn}, \mathrm{Pb}$, and $\mathrm{As}$ being the main determinants of aquatic pollution pattern. Communities of microorganisms present in the sediments are mainly affected by heavy metal pollution. Some groups of bacteria can be considered pollution bio-indicators, due to their sensibility and ability to bioaccumulate heavy metals, thus contributing to reducing pollution. This study investigates the relationships between trace element accumulation and heterogeneity in sediment bacteria community structure found in water streams adjacent to the Bor Copper Smelter Complex (RTB Bor, Serbia). Our results showed no contamination with copper, zinc, nickel, iron, and chromium, but did show a low to moderate contamination with lead and a moderate to high contamination with arsenic in aquatic sediments within the area of interest. Spatial heterogeneity in sediment-associated bacterial communities did not relate significantly to location of sampling sites, except for iron reducing bacteria. Iron reducing bacteria and nitrifying bacteria were the best distinguishing groups of bacteria. However, only iron reducing bacteria were significantly influenced by sampling locations. The iron reducing bacteria has correlated negatively with the degree of sediment contamination with lead, and therefore, we suggest that this group of bacteria could serve as potential bio-indicators of inorganic water contamination in Bor RTB area.
\end{abstract}

Key-words: bacterial community / sediments / heavy metals pollution

Résumé - L'impact environnemental de l'exploitation minière aux alentours de Bor comme indiqué par la distribution de métaux lourds et la dynamique de population bactérienne dans le sédiments. L'impact environnemental de la pollution inorganique est détecté dans l'eau adjacente à la fonderie de cuivre de la ville de Bor (RTB Bor, Serbie), le $\mathrm{Cu}, \mathrm{Zn}, \mathrm{Pb}$, et As étant les principaux déterminants du schéma de pollution aquatique. Les communautés de micro-organismes présents dans les sédiments sont les plus touchés par la pollution des métaux lourds. Certains groupes de bactéries peuvent être considérés comme bio-indicateurs de pollution par leur sensibilité, leur capacité à bio-accumuler d'autres métaux et à contribuer à réduire la pollution. Cette étude s'est penchée sur la relation entre l'accumulation d'oligo-éléments et l'hétérogénéité dans la structure du sédiment de la communauté bactérienne, dans les courants d'eau à proximité de la fonderie de cuivre de la ville de Bor (RTB BOR, Serbie). Nos résultats n'ont montré aucune contamination par le cuivre, zinc, nickel, fer et chrome, mais une contamination faible à modérée par le plomb, et une contamination modérée à forte par l'arsenic dans les sédiments aquatiques des zones d'intérêts. L'hétérogénéité spatiale dans les communautés bactériennes associées aux sédiments n'a pas de lien significatif avec l'emplacement des sites de prélèvements, à l'exception des bactéries réduisant le fer. Les bactéries réduisant le fer et les bactéries nitrifiantes étaient les meilleurs groupes distinctifs de bactéries; ils étaient fortement influencés par l'emplacement de sites d'échantillonnage. Les bactéries réduisant le fer sont négativement corrélées au degré de contamination par le plomb, et par conséquent nous proposons que ce groupe de bactéries serve comme potentiel bio-indicateur de contamination inorganique dans l'eau adjacente à RTB Bor.

Mots-clés : communauté bactérienne / sédiments / pollution avec les métaux lourds

\footnotetext{
^ Corresponding author: popescu.roxana@umft.ro
} 


\section{Introduction}

Sources of water pollution in the Bor area are: waste and drainage water from on-going mining activity, drainage water from the flotation tailings which are no longer in function, overburden dumps from old inactive mine, city-urban wastewater, which is discharged without treatment directly into the Bor River. These wastewaters are a direct source of pollution for the Bor and Krivelj River, which then flow into the Bela River. The on-going mining activity (production of sulphuric acid, copper electrolytic refining, production of copper sulphate and processing of slime anode) has the biggest pollution impact on the Bor River (Bugarin et al., 2013; Marinkové et al., 2014).

The copper mining and smelting operations located in Bor (Serbia) are among the largest nonferrous metal processing plants in Europe (Nikolic et al., 2010). As a result, the Bor River, which collects the water from most water streams in this region, is one of the most contaminated rivers in Europe (Simić, 2007; Petrović et al., 2013) being exposed to long-term inorganic contamination (Petković, 2009).

The Borska Reka River crosses the region of Bor, which is well known for the extensive soil, water, and air pollution with inorganic compounds caused by non-ferrous metal mining, smelting, and processing operations located in this area (Dragićević et al., 2011). The basin of Bela River includes: Krivelj River with its tributaries; Cerova River with its tributaries; Bor River with its tributaries; Ravna River with its tributaries (Obradović et al., 2012).

The Ravna River is located relatively far from the major current pollution sources within the Bor area, such as Cerovo, Bor, or Krivelj open pit mines. By contrast, the Kriveljska River collects the highly polluted waters of the Cerova River and passes next to the Bor open pit mine (Stevanović et al., 2009). Together with additional sources of polluted waters, such as wastewaters from the "Jama Bor" underground mine or other types of industrial waters, it is estimated that almost 1285 tons of iron $(\mathrm{Fe}), 502$ tons of copper $(\mathrm{Cu}), 52$ tons of zinc $(\mathrm{Zn}), 6$ tons of manganese $(\mathrm{Mn}), 2$ tons of lead $(\mathrm{Pb})$, 1.5 tons of nickel (Ni), 0.5 tons of arsenic (As), and 0.3 tons of cadmium $(\mathrm{Cd})$ are being discharged every year, in the hydrographic basin of the Bor River (Panias, 2006).

Several studies reported on elevated level of various trace elements (TE), such as copper $(\mathrm{Cu})$, lead $(\mathrm{Pb})$, zinc $(\mathrm{Zn})$, nickel (Ni), chromium (Cr), and arsenic (As) accumulate in aquatic sediments within the Bor River Basin (Nikolic et al., 2010; Milijašević et al., 2011).

In specific literature, there is a study based on the use of the water pollution index (WPI) presenting a geographical approach on the assessment of water quality within the Timok River Basin. They also reveal a general evaluation of the rivers' health, tacking into account many biotic parameters and abiotic factors, such as: dissolved $\mathrm{O}_{2}, \mathrm{O}_{2}$ saturation, $\mathrm{pH}$, suspended sediments, $\mathrm{BOD}_{5}$, $\mathrm{Cod}_{\mathrm{Mn}}$, nitrites, nitrates, orthophosphates, ammonium, metals (Fe, $\mathrm{Mn}, \mathrm{Hg}, \mathrm{Cu}, \mathrm{Pb}, \mathrm{Zn}$, $\mathrm{Cd})$, sulphates and coliform germs. According to the calculated WPI values, the Borska Reka is classified into Class VI, meaning heavily polluted (Milijašević et al., 2011).

A recent study revealed that these water streams accommodate bacterial life although higher organisms are poorly represented in native aquatic ecosystems (Simić, 2007). Therefore, one can conclude that sediment microbial communities may serve as potential bioindicators to assess the impact of inorganic contamination on environmental health in the Bor area. This approach may overcome the drawbacks encountered when environmental quality is being assessed using various geochemical bioindicators, such as the enrichment factor (ER) or the geoaccumulation index $\left(I_{\text {geo }}\right)$. Such bioindicators accurately measure sediment contamination (Abrahim and Parker 2008; Shafie et al., 2013), but do not provide relevant information concerning its biological implications.

Microbial communities are key players for metal mobility in soils or sediments, and as a consequence, the spatial and temporal heterogeneity of native bacterial biota is frequently associated with the extent of inorganic pollution (Thiyagarajan et al., 2010). It was found that bacterial biota responds differently to metal exposure, depending on environmental conditions (Gillan et al., 2012). Thus, trace metals were shown to inhibit microbial biomass and diversity in certain environments (Muyzer et al., 2008; Gillan et al., 2012), whereas in other environments even elevated levels of trace metals had no effect on bacterial biomass and diversity (Bouskill et al., 2010; Pringault et al., 2010).

Studies on the soil/sediment highlights the impact of metal contamination on the groups of bacteria involved in the nitrogen cycle. $\mathrm{Pb}$ contamination of the soil affects the bacteria involved in the nitrogen cycle, nevertheless denitrifying bacteria seem to adapt to high concentrations of $\mathrm{Pb}$ (Sobolev and Begonia, 2008). Other studies report decreases in activity and the number of ammonifying and denitrifying bacteria in soil contamination with $\mathrm{Zn}, \mathrm{Pb}, \mathrm{Cu}$ and $\mathrm{Hg}$ ( $\mathrm{Li}$ et al., 2009; Liu et al., 2010, 2014; Ruyters et al., 2010; Magalhães et al., 2011). Significant decreases are being registered in sediment activity and in the number of denitrifying bacteria in case of contamination with $\mathrm{Cd}, \mathrm{Cu}$ or $\mathrm{Zn}$ (Sakadevan et al., 1999). Another study analyses the effect of pollution with sulphate reducing bacteria. The results of this study suggest that SRB from metal-contaminated environments have a markedly higher metal tolerance than those enriched from uncontaminated environments (Jin et al., 2007). The contamination with $\mathrm{Cu}$ resulted in an increased time reduction of Fe (III) and a reduction in the rate of metabolism. The study demonstrates that $\mathrm{Cu}$ toxicity impedes anaerobic carbon oxidation and bacterial reduction of hydrous ferric oxide (Markwiese and Colberg, 2000).

Five bacterial groups (sulphate reducing bacteria (SRB), iron reducing bacteria (IRB), ammonifying bacteria (AMB), denitrifying bacteria (DNB) and nitrifying bacteria (NB)) were considered in the present work based on their ecophysiological role in aquatic ecosystems and potential application for environmental biomonitoring and bioremediation. To the extent of our knowledge, this is the first study that addresses the shifts induced by inorganic water contamination to the dynamics of bacterial communities in aquatic bed sediments from water streams adjacent to the Bor Copper Smelter Complex (RTB Bor, Serbia). The results of this study are important, because the Bor River poses a serious threat to many other river-based communities in the Western Balkans and to the Lower Danube Basin. 


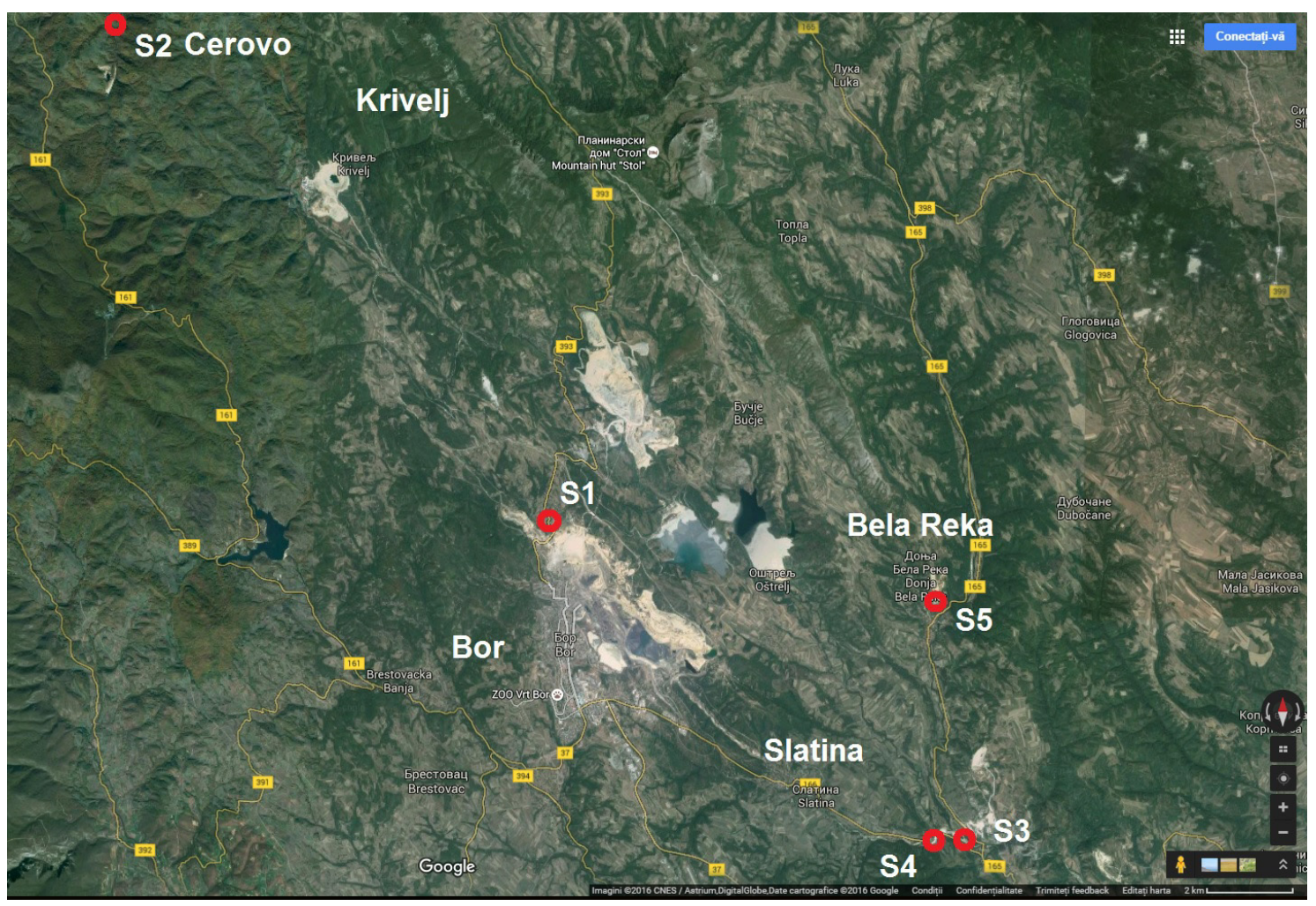

Fig. 1. Map showing the location of sampling sites - Legend. S1, site S1 (44.5368 lat. N, $22.5403^{\circ}$ long. E); S2, site S2 (44.1018 ${ }^{\circ}$ lat. N, $22.1548^{\circ}$ long. E); S3, site S3 (44.1512 ${ }^{\circ}$ lat. N, $22.1238^{\circ}$ long. E); S4, site S4 (44.1466 lat. N, $22.1229^{\circ}$ long. E); S5, site S5 (44.4593 lat. N, $22.1385^{\circ}$ long. E).

The aim of this study was to determine the impact of mining activities on surface waters, based on the level of water contamination by heavy metals found in the Bor mining area, and determines the bioaccumulation index and impact of heavy metals on the dynamics of bacterial communities living in the sediment.

\section{Materials and methods}

\subsection{Study areas}

In this study, five tapping points have been chosen to collect water and sediment samples that were representative for the hydrologic system surrounding the city of Bor (Figure 1). All sampling sites were located within a $15 \mathrm{~km}$ radius of the Bor city, and at different distances from actual sources of inorganic contamination, such as the Bor, Cerovo, or Krivelj open pits (Figure 1). The first tapping point (S1) is located near the "Jama Bor" underground mine. The second tapping point is the Lutarica River, which passes near the Cerovo pit mine (closed in 2002 and then reopened in 2012). The third tapping point (S3) and the fourth tapping point (S4) lie close to each other and near the confluence of the Bor and Kriveljska rivers. Both rivers flow north to south, passing nearby major sources of inorganic contamination; the Bor River passes nearby the Bor open pit mine and the Kriveljska River passes nearby the Krivelj open pit mine. The fifth sampling point (S5) is the Ravna River; although this water stream was not affected by anthropic pollution during the past decades or so, there is strong evidence to suggest this site was also exposed to inorganic contamination during the Roman Empire (Petković, 2009).

\subsection{Chemical and microbiological analysis}

To provide relevant results, the sediment samples were collected in four different campaigns (summer 2011, autumn 2011, spring 2012, and summer 2012) from five sites that were placed at different distances from the main sources of inorganic contamination around the city of Bor. The samples were collected in triplicate from the top layer of aquatic bed sediments, were placed inside sterile bottles, preserved in a cooler bag (at a temperature of $+4{ }^{\circ} \mathrm{C}$ ), and transported to the Microbiology Laboratory from West University of Timisoara (Romania).

To determine the levels to which trace elements accumulate in aquatic sediments, the samples $(100 \mathrm{~mL} / \mathrm{each}$ sample) were oven dried at a temperature of $105{ }^{\circ} \mathrm{C}$, for $48 \mathrm{~h}$, and weighed using an analytical balance to the nearest $0.01 \mathrm{mg}$. Ultrapure nitric acid $\left(\mathrm{HNO}_{3} 65 \%, \rho=1.39 \mathrm{~g} \cdot \mathrm{cm}^{-3}\right)$ was purchased from Sigma-Aldrich Chemie GmbH (Buchs, Switzerland) to prepare the necessary digestion solutions. After burning inside a muffle furnace, the resulting ash was dissolved in $20 \mathrm{~mL}$ of $0.5 \mathrm{~N} \mathrm{HNO}_{3}$ solution and then filtered through ash-free filter paper. For each sample, the volume was brought to $50 \mathrm{~mL}$ with $30 \mathrm{~mL}$ of $0.5 \mathrm{~N} \mathrm{HNO}_{3}$ solution. Trace 
metal analyses were conducted by using flame atomic absorption spectrophotometry with an acetylene-nitrous oxide flame (Perkin-Elmer 403 AAS). Percentage recoveries for trace elements ranged from $85 \%$ to $105 \%$. The concentration of trace elements in aquatic sediments was expressed as microgram per gram dry weight $\left(\mu \mathrm{g} \cdot \mathrm{g}^{-1}\right.$ dry wt).

Serial decimal dilutions were prepared from sediments $\left(10^{-1}-10^{-6}\right)$ for each sample using double-distilled, sterile water, and were inoculated in selective culture medium. The number of bacteria was estimated according to the multiple-tube method.

Sulphate reducing bacteria (SRB) were cultivated on a Starkey's medium, with the following chemical composition: $\mathrm{Na}_{3} \mathrm{PO}_{4}(5 \mathrm{~g}), \mathrm{NH}_{4} \mathrm{Cl}(1 \mathrm{~g}), \mathrm{K}_{2} \mathrm{HPO}_{4}(0.5 \mathrm{~g})$, $\mathrm{MgSO}_{4} .7 \mathrm{H}_{2} \mathrm{O}(2 \mathrm{~g}), \mathrm{Na}_{2} \mathrm{SO}_{4}(0.5 \mathrm{~g}), \mathrm{CaCl}_{2} 2 \mathrm{H}_{2} \mathrm{O}(0.1 \mathrm{~g})$, $\left(\mathrm{NH}_{4}\right) \mathrm{Fe}\left(\mathrm{SO}_{4}\right)_{2} 6 \mathrm{H}_{2} \mathrm{O}(0.01 \mathrm{~g})$ (Domagala et al., 1992). Incubation was done at $28{ }^{\circ} \mathrm{C}$ for 14 days. Positive tubes are considered to have a black precipitate at the bottom (iron sulphide).

In order to determine the iron-reducing bacteria (IRB) the following Ottow culture media with modified chemical composition was used: glucose $(20 \mathrm{~g})$, peptone $(5 \mathrm{~g})$, yeast extract (0.5 g), $\mathrm{MgSO}_{4} .7 \mathrm{H}_{2} \mathrm{O}(0.2 \mathrm{~g}), \mathrm{K}_{2} \mathrm{HPO}_{4}(3 \mathrm{~g}), \mathrm{KH}_{2} \mathrm{PO}_{4}(0.8 \mathrm{~g})$, $\mathrm{KCl}(0.2 \mathrm{~g}), \mathrm{Fe}_{2} \mathrm{O}_{3} .3 \mathrm{H}_{2} \mathrm{O}(1 \mathrm{~g})$. The samples were incubated for 14 days, at $28{ }^{\circ} \mathrm{C}$. $\mathrm{Fe}^{2+}$ ions, produced by iron-reducing bacteria, can be highlighted by adding $0.1 \mathrm{~mL}$ of reactive $\alpha, \alpha$ dipiridil to $0.7 \mathrm{~mL}$ of culture. The red or pink color indicates the presence of $\mathrm{Fe}^{2+}$ ions (Drăgan-Bularda, 2000).

The culture medium for ammonifying bacteria (AMB) had the following chemical composition: $\mathrm{NaCl}(0.5 \mathrm{~g})$, peptone $(2 \mathrm{~g})$, distilled water $(1000 \mathrm{~mL})$. The samples were incubated for 14 days, at $28{ }^{\circ} \mathrm{C}$. AMB number was assessed based on the reaction between ammonia and Nessler reagent $\left[\mathrm{K}_{2}\left(\mathrm{HgI}_{4}\right)\right]$; the Alexander table was used as screening benchmark (Drăgan-Bularda, 2000).

The culture medium for nitrifying bacteria (NB) consisted of standard saline traces $(50 \mathrm{~mL}),\left(\mathrm{NH}_{3}\right) \mathrm{SO}_{4}(0.5 \mathrm{~g}), \mathrm{CaCO}_{3}$ $(1 \mathrm{~g})$, and distilled water $(950 \mathrm{~mL})$. Samples were incubated for 21 days, at $28{ }^{\circ} \mathrm{C}$. Tubes containing nitrate were identified with diphenylamine sulphuric acid. A blue colour reaction showed that nitrite and nitrate were formed, and therefore, the tube was scored positive (Cappucino and Sherman, 2008).

The denitrifying bacteria (DNB) were grown in selective culture medium, which contained: standard saline solution $(50 \mathrm{~mL}), \mathrm{KNO}_{2}(20 \mathrm{~g})$, glucose $(10 \mathrm{~g}), \mathrm{KCO}_{3}(5 \mathrm{~g})$, oligoelement solution $(1 \mathrm{~mL})$, and distilled water. The samples were incubated at $28{ }^{\circ} \mathrm{C}$, for 14 days, and diphenylamine-sulphuric acid was added in each test tube. Positive samples were colourless due to nitrate metabolization by DNB (Dunca et al., 2007).

\subsection{Statistical analysis}

The geoaccumulation Index $\left(I_{\mathrm{geo}}\right)$, was calculated in order to determine the degree of metal accumulation in sediments by using the formula:

$$
I_{\text {geo }}=\log _{2} C_{n} / 1.5 B_{n}
$$

where $C_{n}$ defines the concentration of element in sediments, $B_{n}$ the geochemical background value, and the factor 1.5 accounts for possible variation in background data due to lithogenic effect (Yisa et al., 2012). When the measured values did exceed 0.5 , a non-parametric analysis was conducted to assess possible differences among sampling sites (Mood's Median test). A One-Way Analysis of Similarity (Anosim) using the BrayCurtis similarity measure was performed, in order to determine whether there is a significant difference between the sampling units or not.

This non-parametric test generates a global value of $R$ that ranges between +1 and -1 ; a value of 0 shows no differences among the samples. Comparison of pair-wise $R$ values defines on a scale of 0 (indistinguishable) to 1 (all similarities within groups are less than any similarity between groups) differences existing between groups: $R>0.75$ as well separated groups; $R>0.5$ as overlapping groups; $R<0.25$ as barely separable groups (Clarke and Gorley, 2001). The $p$-values were corrected for multiple testing by a Bonferroni correction. Next, a Similarity Percentage Analysis (Simper) was conducted to identify which ecophysiological groups of bacteria accounted for most spatial dissimilarities observed in the dynamics of bacterial population dynamics.

The spatial differences in population's dynamics for each bacteria group were then compared statistically using KruskalWallis tests. Spearman's rank-order correlation coefficients were finally computed to determine the existing relationships between the dynamics of bacterial population and metal concentrations in aquatic bed sediments.

Statistical analysis was performed using Past (Hammer et al., 2001) and Statistica 10 software packages. All data is presented as the median $\pm \mathrm{SE}$, as the samples were processed in triplicate. A $p$ value $<0.05$ was considered significant.

\section{Results}

Table 1 contains trace element concentrations $\left(\mu \mathrm{g} \cdot \mathrm{g}^{-1}\right)$ and Table 2 contains geoaccumulation indices $\left(I_{\text {geo }}\right)$ in aquatic sediments, depending on site location and sampling season. The measured values for $\mathrm{Cu}, \mathrm{Zn}, \mathrm{Ni}$, and $\mathrm{Cr}$ indicated no contamination with these trace elements in the study area. There was a low to moderate contamination with $\mathrm{Pb}$, and a moderate to high contamination with As in aquatic bed sediments. In the majority of heavy metals cases, the highest mean $I_{\text {geo }}$ values for these metals were reported at the sites S2 and S3, whereas the lowest values were found for at the site $\mathrm{S} 1$. The site location had no influence on the degree of lead contamination (Mood's Median test, $p=0.199$ ), but significantly influenced the arsenic accumulation in aquatic sediments (Mood's Median test, $p=0.040$ ).

The population dynamics for different groups of sediment bacteria are described in Table 3. The assessment by Anosim revealed no significant spatial differences in bacterial population structure among different locations (Global $R=0.106$, $p=0.065)$. The population dynamics were similar at the sites $\mathrm{S} 1$ and $\mathrm{S} 2(R=0.020, p=1.000)$, and $\mathrm{S} 1$ and $\mathrm{S} 3(R=0.020$, $p=1.000)$. Identical results were found between the sites $\mathrm{S} 1$ and S5 $(R=0.104, p=1.000)$, and S2 and S4 $(R=0.104$, $p=1.000)$. High similarities in quantitative population dynamics were also reported at the sites $\mathrm{S} 1$ and $\mathrm{S} 4(R=0.062$, $p=1.000), \mathrm{S} 2$ and $\mathrm{S} 3(R=0.041, p=1.000), \mathrm{S} 3$ and $\mathrm{S} 4$ 
Table 1. Trace element concentrations in aquatic bed sediments from water streams adjacent to the Copper Smelter Complex Bor (RTB Bor, Serbia) depending on site location and sampling season.

\begin{tabular}{|c|c|c|c|c|c|c|}
\hline & \multicolumn{6}{|c|}{ Trace element concentration } \\
\hline Site & $\mathrm{Cu}\left(\mu \mathrm{g} \cdot \mathrm{g}^{-1}\right)$ & $\mathrm{Pb}\left(\mu \mathrm{g} \cdot \mathrm{g}^{-1}\right)$ & $\mathrm{Zn}\left(\mu \mathrm{g} \cdot \mathrm{g}^{-1}\right)$ & $\mathrm{Ni}\left(\mu \mathrm{g} \cdot \mathrm{g}^{-1}\right)$ & $\mathrm{Cr}\left(\mu \mathrm{g} \cdot \mathrm{g}^{-1}\right)$ & As $\left(\mu \mathrm{g} \cdot \mathrm{g}^{-1}\right)$ \\
\hline 1.1. & $497.0 \pm 261.2$ & $45.32 \pm 10.2$ & $87.82 \pm 42.5$ & $4.62 \pm 0.92$ & $34.21 \pm 12.90$ & $96.21 \pm 23.08$ \\
\hline 1.2. & $1491 \pm 190.2$ & $125.6 \pm 23.2$ & $137.5 \pm 54.2$ & $4.695 \pm 0.23$ & $13.593 \pm 12.09$ & $182.70 \pm 76.14$ \\
\hline 1.3. & $1097.5 \pm 319$ & $160.9 \pm 39.9$ & $140.4 \pm 72.9$ & $3.272 \pm 1.274$ & $10.722 \pm 5.894$ & $259.3 \pm 172.07$ \\
\hline 1.4. & $1748 \pm 424.7$ & $64.90 \pm 17.0$ & $106.7 \pm 43.7$ & $5.424 \pm 0.254$ & $15.985 \pm 7.439$ & $24.127 \pm 12.99$ \\
\hline 1.5. & $324.1 \pm 281.5$ & $43.12 \pm 9.34$ & $222.1 \pm 83.2$ & $7.29 \pm 1.712$ & $13.907 \pm 12.09$ & $13.723 \pm 5.096$ \\
\hline 2.1 & $363.6 \pm 120.5$ & $47.38 \pm 12.7$ & $231.2 \pm 31.5$ & $7.539 \pm 0.925$ & $13.563 \pm 2.055$ & $17.693 \pm 12.85$ \\
\hline 2.2 & $3770.8 \pm 501$ & $262.9 \pm 42.3$ & $2294 \pm 305$ & $11.22 \pm 2.157$ & $77.88 \pm 54.737$ & $333.72 \pm 154.4$ \\
\hline 2.3 . & $4433.8 \pm 320$ & $400.1 \pm 59.6$ & $3241 \pm 577$ & $12.871 \pm 2.81$ & $120.3 \pm 48.862$ & $523.1 \pm 187.96$ \\
\hline 2.4. & $3982.5 \pm 448$ & $360.1 \pm 41.7$ & $2923 \pm 219$ & $11.13 \pm 1.997$ & $121.02 \pm 51.99$ & $450.72 \pm 152.2$ \\
\hline 2.5 & $6283 \pm 1218$ & $480.1 \pm 39.2$ & $7150 \pm 1023$ & $17.528 \pm 3.06$ & $211.17 \pm 79.45$ & $858.59 \pm 302.6$ \\
\hline 3.1. & $515.6 \pm 257.6$ & $66.22 \pm 13.0$ & $221.7 \pm 51.0$ & $4.229 \pm 0.416$ & $20.652 \pm 13.63$ & $92.754 \pm 43.02$ \\
\hline 3.2. & $2851.6 \pm 403$ & $211.7 \pm 51.2$ & $1170 \pm 286$ & $5.203 \pm 0.684$ & $40.944 \pm 28.78$ & $309.94 \pm 152.2$ \\
\hline 3.3 . & $1537.7 \pm 284$ & $120.8 \pm 27.3$ & $1735 \pm 359$ & $14.85 \pm 1.274$ & $15.229 \pm 8.502$ & $257.57 \pm 104.4$ \\
\hline 3.4 & $2142.1 \pm 430$ & $81.55 \pm 9.09$ & $1470 \pm 477$ & $4.772 \pm 0.619$ & $113.38 \pm 73.95$ & $223.32 \pm 38.86$ \\
\hline 3.5. & $4348.4 \pm 385$ & $115.4 \pm 17.2$ & $7190 \pm 1301$ & $16.81 \pm 3.219$ & $125.5 \pm 174.09$ & $721.8 \pm 302.94$ \\
\hline 4.1. & $501.7 \pm 131.0$ & $56.1 \pm 16.05$ & $152.7 \pm 72.9$ & $5.44 \pm 1.441$ & $23.61 \pm 13.05$ & $32.74 \pm 21.623$ \\
\hline 4.2. & $2585.6 \pm 494$ & $151.6 \pm 25.0$ & $2170 \pm 567.0$ & $7.202 \pm 1.723$ & $54.9 \pm 24.1$ & $219.5 \pm 132.03$ \\
\hline 4.3. & $3237 \pm 1020$ & $220.8 \pm 6.25$ & $1873.5 \pm 510$ & $8.896 \pm 1.529$ & $103.2 \pm 75.02$ & $335.8 \pm 152.44$ \\
\hline 4.4. & $2945.2 \pm 306$ & $218.5 \pm 26.5$ & $1773.5 \pm 490$ & $6.71 \pm 1.204$ & $117.32 \pm 37.94$ & $237.89 \pm 87.70$ \\
\hline 4.5. & $4847.4 \pm 881$ & $215.9 \pm 30.0$ & $6372 \pm 1756$ & $13.80 \pm 3.71$ & $178.53 \pm 16.09$ & $681.2 \pm 172.90$ \\
\hline
\end{tabular}

Note. Trace element concentrations (values - the median \pm SE), 1.1., site S1 (July 2011); 1.2., site S2 (July 2011); 1.3., site S3 (July 2011); 1.4., site S4 (July 2011); 1.5., site S5 (July 2011); 2.1., site S1 (November 2011); 2.2., site S2 (November 2011); 2.3., site S3 (November 2011); 2.4., site S4 (November 2011); 2.5., site S5 (November 2011); 3.1., site S1 (March 2012); 3.2., site S2 (March 2012); 3.3., site S3 (March 2012); 3.4., site S4 (March 2012); 3.5., site S5 (March 2012); 4.1., site S1 (July 2012); 4.2., site S2 (July 2012); 4.3., site S3 (July 2012 ); $4.4 .$, site S4 (July 2012); 4.5., site S5 (July 2012).

Table 2. Geoaccumulation indices in aquatic bed sediments from water streams adjacent to the Copper Smelter Complex Bor (RTB Bor, Serbia) depending on site location and sampling season.

\begin{tabular}{lcccccc}
\hline Site & $\mathrm{Cu}$ & $\mathrm{Pb}$ & $\mathrm{Zn}$ & $\mathrm{Ni}$ & $\mathrm{Cr}$ & $\mathrm{As}$ \\
\hline 1.1. & 0.087 & 0.367 & 0.054 & 0.016 & 0.024 & 2.091 \\
1.2. & 0.103 & 0.465 & 0.060 & 0.016 & 0.018 & 2.385 \\
1.3. & 0.099 & 0.489 & 0.060 & 0.012 & 0.016 & 2.545 \\
1.4. & 0.105 & 0.401 & 0.057 & 0.018 & 0.019 & 1.457 \\
1.5. & 0.081 & 0.362 & 0.066 & 0.021 & 0.018 & 1.199 \\
2.1. & 0.084 & 0.371 & 0.066 & 0.022 & 0.018 & 1.313 \\
2.2. & 0.116 & 0.536 & 0.094 & 0.026 & 0.030 & 2.661 \\
2.3. & 0.118 & 0.576 & 0.098 & 0.027 & 0.033 & 2.867 \\
2.4. & 0.117 & 0.566 & 0.097 & 0.026 & 0.033 & 2.799 \\
2.5. & 0.123 & 0.594 & 0.108 & 0.031 & 0.037 & 3.094 \\
3.1. & 0.088 & 0.403 & 0.066 & 0.015 & 0.021 & 2.074 \\
3.2. & 0.112 & 0.515 & 0.086 & 0.018 & 0.025 & 2.627 \\
3.3. & 0.103 & 0.461 & 0.091 & 0.029 & 0.019 & 2.542 \\
3.4. & 0.108 & 0.423 & 0.089 & 0.017 & 0.032 & 2.477 \\
3.5. & 0.118 & 0.457 & 0.108 & 0.030 & 0.033 & 3.014 \\
4.1. & 0.087 & 0.387 & 0.061 & 0.018 & 0.022 & 1.597 \\
4.2. & 0.111 & 0.483 & 0.094 & 0.021 & 0.028 & 2.469 \\
4.3. & 0.114 & 0.519 & 0.092 & 0.023 & 0.032 & 2.664 \\
4.4. & 0.113 & 0.518 & 0.091 & 0.020 & 0.033 & 2.506 \\
4.5. & 0.120 & 0.517 & 0.107 & 0.028 & 0.036 & 2.988 \\
\hline
\end{tabular}

Note. 1.1., site S1 (July 2011); 1.2., site S2 (July 2011); 1.3., site S3 (July 2011); 1.4., site S4 (July 2011); 1.5., site S5 (July 2011); 2.1., site S1 (November 2011); 2.2., site S2 (November 2011); 2.3., site S3 (November 2011); 2.4., site S4 (November 2011); 2.5., site S5 (November 2011); 3.1., site S1 (March 2012); 3.2., site S2 (March 2012); 3.3., site S3 (March 2012); 3.4., site S4 (March 2012); 3.5., site S5 (March 2012); 4.1., site S1 (July 2012); 4.2., site S2 (July 2012); 4.3., site S3 (July 2012); 4.4., site S4 (July 2012); 4.5., site S5 (July 2012). 
Table 3. Bacteria population dynamics in aquatic bed sediments from water streams adjacent to the Copper Smelter Complex Bor (RTB Bor, Serbia) depending on site location and sampling season (no bacteria/ $1 \mathrm{~g}$ sediment).

\begin{tabular}{lccccc}
\hline & SRB & IRB & AMB & NB & DNB \\
\hline 1.1. & $1712.32 \pm 173$ & $4522.85 \pm 603$ & $2429.76 \pm 306$ & $66812.98 \pm 5091$ & $2291.08 \pm 365$ \\
1.2. & $610.86 \pm 234$ & $5401.21 \pm 774$ & $2312.40 \pm 120$ & $25971.87 \pm 3825$ & $2002.05 \pm 196$ \\
1.3. & $1703.98 \pm 14$ & $3598.82 \pm 451$ & $3228.83 \pm 298$ & $5921.95 \pm 20$ & $1725.87 \pm 304$ \\
1.4. & $422.20 \pm 56$ & $2476.99 \pm 102$ & $3875.09 \pm 104$ & $6984.25 \pm 413$ & $2183.81 \pm 424$ \\
1.5. & $1405.92 \pm 253$ & $4414.65 \pm 705$ & $3217.74 \pm 297$ & $8156.09 \pm 20$ & $1788.33 \pm 56$ \\
2.1. & $2082.04 \pm 384$ & $66275.20 \pm 3012$ & $43074.35 \pm 3683$ & $1073.81 \pm 292$ & $2473.86 \pm 534$ \\
2.2. & $1204.55 \pm 185$ & $1739.87 \pm 87$ & $2328.63 \pm 95$ & $820.02 \pm 124$ & $810.10 \pm 163$ \\
2.3. & $2087.28 \pm 128$ & $4028.93 \pm 564$ & $3656.99 \pm 225$ & $1786.78 \pm 612$ & $937.75 \pm 128$ \\
2.4. & $1728.25 \pm 421$ & $1128.38 \pm 241$ & $8137.84 \pm 1223$ & $1725.08 \pm 312$ & $1934.02 \pm 493$ \\
2.5. & $2403.90 \pm 104$ & $3627.27 \pm 201$ & $4548.08 \pm 177$ & $4812.95 \pm 423$ & $1727.62 \pm 305$ \\
3.1. & $2389.98 \pm 309$ & $4078.72 \pm 809$ & $2803.05 \pm 402$ & $3724.13 \pm 582$ & $424.97 \pm 103$ \\
3.2. & $3862.76 \pm 127$ & $1898.98 \pm 427$ & $2321.81 \pm 305$ & $1427.86 \pm 203$ & $2244.88 \pm 93$ \\
3.3. & $2116.11 \pm 149$ & $2157.73 \pm 525$ & $740.90 \pm 266$ & $1746.35 \pm 241$ & $2105.22 \pm 387$ \\
3.4. & $1773.87 \pm 209$ & 0 & $2879.25 \pm 455$ & $14811.97 \pm 3816$ & $1736.65 \pm 405$ \\
3.5. & $1211.21 \pm 138$ & $2226.76 \pm 305$ & $2472.36 \pm 254$ & $28613.62 \pm 3149$ & $1474.86 \pm 287$ \\
4.1. & $2233.40 \pm 364$ & $4675.30 \pm 398$ & $3291.07 \pm 402$ & $2458.76 \pm 413$ & $1809.24 \pm 439$ \\
4.2. & $1765.29 \pm 259$ & $1728.07 \pm 102$ & $2582.91 \pm 243$ & $2146.97 \pm 398$ & $1736.97 \pm 325$ \\
4.3. & $1512.12 \pm 243$ & $2663.93 \pm 405$ & $3891.01 \pm 412$ & $1863.80 \pm 241$ & $1293.86 \pm 298$ \\
4.4. & $1329.07 \pm 98$ & $1627.27 \pm 306$ & $4200.08 \pm 805$ & $2153.64 \pm 103$ & $1423.33 \pm 142$ \\
4.5. & $1873.08 \pm 565$ & $3825.72 \pm 298$ & $4812.97 \pm 561$ & $7828.98 \pm 429$ & $1598.97 \pm 238$ \\
\hline
\end{tabular}

Note. SRB - sulfate-reducing bacteria; IRB - iron reducing bacteria; AMB - ammonifying bacteria; DNB - denitrifying bacteria; NB nitrifying bacteria; 1.1., site S1 (July 2011); 1.2., site S2 (July 2011); 1.3., site S3 (July 2011); 1.4., site S4 (July 2011); 1.5., site S5 (July 2011); 2.1., site S1 (November 2011); 2.2., site S2 (November 2011); 2.3., site S3 (November 2011); 2.4., site S4 (November 2011); 2.5 ., site S5 (November 2011); 3.1., site S1 (March 2012); 3.2., site S2 (March 2012); 3.3., site S3 (March 2012); 3.4., site S4 (March 2012); 3.5., site S5 (March 2012); 4.1., site S1 (July 2012); 4.2., site S2 (July 2012); 4.3., site S3 (July 2012); 4.4., site S4 (July 2012); 4.5., site S5 (July 2012).

$(R=0.083, p=1.000), \mathrm{S} 3$ and S5 $(R=0.197, p=0.869)$, and S4 and S5 $(R=0.166, p=1.000)$, respectively. The greatest dissimilarity was observed between sites S2 and S5 $(R=0.364, p=1.000)$.

The results of Simper analysis showed that IRB and NB were the best discriminating groups of bacteria, accounting for $63.20 \%$ of the overall average dissimilarity among study in the studied areas (Table 4). However, the population dynamics of sediment bacteria was shown to be significantly different among sites only for IRB (Kruskal-Wallis test, $p=0.022$ ), but not for SRB, AMB, ND, and DNB (Kruskal-Wallis test, 0.112 $<p<0.779$ ). Among sediment bacteria groups, only the population dynamics of IRB and DNB were significantly related to the degree of sediment contamination (Table 5). Thus, IRB were reversely associated with $I_{\text {geo }}$ for $\mathrm{Cu}, \mathrm{Pb}$, and $\mathrm{Cr}$, whereas DNB was negatively correlated with $I_{\text {geo }}$ for $\mathrm{Zn}$ and $\mathrm{Cr}$.

\section{Disscusion}

Studies regarding the level of water pollution in Bor area had included several biotic and abiotic parameters. The general conclusion is that the values of some parameters that indicate organic pollution $\left(\mathrm{BOD}_{5}\right.$, ammonium, coliform germs, etc.) and the presence of metals ( $\mathrm{Fe}, \mathrm{Mn}, \mathrm{Cu})$ are far above the permitted limits, indicating severe organic and inorganic pollution in this area. This is a consequence of the activities of various subjects. The main sources of Timok River Basin pol- lution are untreated communal wastewater and the wastewater from the Bor mining industrial complex. The technological processes related to copper ore exploitation and processing in the Bor mining industrial complex generate important quantities of wastewater. The wastewaters from the mining process, as well as the wastewater from metallurgical and chemical processes in industrial plants are both being discharged directly into the Borska Reka. The solution to the problem of water quality and environmental protection lies in the construction of appropriate wastewater treatment plants. The progress in environmental protection and water pollution reduction is the area must be analyzed: in the Bor mining industrial complex the construction of wastewater purification plant was undertaken in 2005; it will enable to separate copper and iron for further processing and to reduce the discharge of untreated water into the Borska Reka River (Brankov et al., 2012).

Despite the high levels of heavy metals and low $\mathrm{pH}$ of the water, this river still accommodates bacterial life. However, no field survey has investigated the effects of extensive inorganic pollution towards sediment bacterial communities. This type of pollution is generally associated with changes in physicochemical properties of the water and enrichment of aquatic sediments with heavy metals (UNESCO/WHO/UNEP, 1996).

Despite being exposed to long-term impact of mining and smelting activities (Serbula et al., 2010), the aquatic bed sediments from water streams adjacent to the Bor Copper Smelter Complex (RTB Bor, Serbia) showed no contamination with either $\mathrm{Cu}, \mathrm{Zn}, \mathrm{Ni}$, or $\mathrm{Cr}$. In our study the values measured for 
M.N. Filimon et al.: Knowl. Manag. Aquat. Ecosyst. (2016) 417, 30

Table 4. Results of Simper analysis with taxon contributions to dissimilarities among sites.

\begin{tabular}{cccccccc}
\hline & & & $\begin{array}{c}\text { Mean } \\
\text { abund. }\end{array}$ & $\begin{array}{c}\text { Mean } \\
\text { abund. }\end{array}$ & $\begin{array}{c}\text { Mean } \\
\text { abund. }\end{array}$ & $\begin{array}{c}\text { Mean } \\
\text { abund. }\end{array}$ & $\begin{array}{c}\text { Mean } \\
\text { abund. }\end{array}$ \\
Taxon & Contribution & Cumulative $\%$ & S1 & S2 & S3 & S4 & S5 \\
\hline IRB & 2.197 & 34.520 & 4.030 & 3.370 & 3.470 & 2.410 & 3.520 \\
NB & 1.862 & 63.750 & 3.790 & 3.450 & 3.370 & 3.630 & 3.980 \\
AMB & 0.896 & 77.840 & 3.740 & 3.370 & 3.380 & 3.640 & 3.560 \\
SRB & 0.875 & 91.600 & 3.310 & 3.170 & 3.000 & 3.040 & 3.220 \\
DNB & 0.534 & 100.000 & 3.140 & 3.200 & 3.150 & 3.240 & 3.200 \\
\hline
\end{tabular}

Note. Mean abund., mean abundance; $I_{\text {geo }}$, geoaccumulation index. Values marked with asterisks $(*)$ define significant correlations $($ Spearman's correlations, $p<0.05)$.

Table 5. Correlations between the population dynamics of sediment bacteria and geoaccumulation index of trace elements.

\begin{tabular}{cccccccc}
\hline & $I_{\text {geo }} \mathrm{Cu}$ & $I_{\text {geo }} \mathrm{Pb}$ & $I_{\text {geo }} \mathrm{Zn}$ & $I_{\text {geo }} \mathrm{Ni}$ & $I_{\text {geo }} \mathrm{Cr}$ & $I_{\text {geo }} \mathrm{As}$ & $I_{\text {geo }} \mathrm{Fe}$ \\
\hline $\mathrm{IRB}$ & $-0.508^{*}$ & $-0.452^{*}$ & -0.439 & -0.191 & $-0.469^{*}$ & -0.416 & -0.320 \\
$\mathrm{NB}$ & -0.179 & -0.438 & -0.278 & -0.292 & -0.012 & -0.137 & -0.278 \\
$\mathrm{AMB}$ & 0.214 & 0.209 & 0.232 & 0.232 & 0.301 & 0.086 & -0.059 \\
$\mathrm{SRB}$ & 0.069 & 0.071 & 0.201 & 0.192 & 0.226 & 0.092 & 0.127 \\
$\mathrm{DNB}$ & -0.433 & -0.405 & $-0.477^{*}$ & -0.194 & $-0.465^{*}$ & -0.403 & -0.259 \\
\hline
\end{tabular}

concentrations of heavy metals $(\mathrm{Pb}, \mathrm{Cu}, \mathrm{Zn}, \mathrm{Ni}, \mathrm{Cr}, \mathrm{As})$ present in the sediments, have exceed the reference values in most cases. Since our study only determined the sediment metal concentrations and abundant groups of bacteria, with no other parameters, we cannot calculate WPI and classify the water in one of the 6 classes. Further study and analysis of several other parameters will allow us to determine water quality according to WPI in the future. Arsenic was found to be the most important factor determining the pattern of inorganic contamination in aquatic bed sediments within the area of interest. High As levels have been reported as suspended particulate matter in the industrial waste waters generated in the primary copper smelter at Bor, Serbia (Giannopoulou and Panias, 2008; Serbula et al., 2010). Since almost 300 tons of inorganic arsenic (As) are being discharged every year in the hydrographic basin of the Bor River (Kovačević et al., 2010), our results are not surprising at all. These findings reflect the risks posed by As contamination on the native aquatic ecosystems.

We observed that the population structure of sediment bacteria biotopes was homogeneous irrespective of location. It was therefore hypothesized that long-term exposure to Asrich sediments resulted in an increased As-resistance in these bacterial biotopes. Such mechanisms are related to the ability of bacteria to methylate soluble toxic inorganic arsenic to the less toxic, organic form (Tamaki and Frankenberger, 1992). Elevated $I_{\text {geo }}$ values for arsenic that are found at the site S5 are of particular interest since this water stream was not affected by anthropic activities during the past decades or so. These results are thought to be associated with the disaffected Roman mines from the Ravna River basin and the upper course of the Pek River, such as those uncovered at Donja Bela Reka (Petkovic, 2009), rather than being related to recent contamination events.

A recent study reported elevated levels of accumulated $\mathrm{Pb}$ in vegetation (Tilia spp., Pinus spp.) sampled around the copper smelter in Bor (Serbula et al., 2013). Serbula et al. (2012) investigated $\mathrm{Pb}$ accumulation in different parts of Robinia pseudoacacia L. (Fabaceae), and showed that leaves and branches acted as excluders, not as indicators of $\mathrm{Pb}$. In this study, by contrast, IRB dynamics was significantly associated with the degree of $\mathrm{Pb}$ contamination. The natural chalcopyrite $\left(\mathrm{CuFeS}_{2}\right)$ ores from the Bor metallogenic zone is rich in lead (Panias, 2006).

The processing of such ores is therefore expected to result in their accumulation in aquatic sediments from water streams adjacent to the Copper Smelter Complex Bor (RTB Bor, Serbia). As a result, IRB are potential bioindicators of inorganic contamination within the area of interest.

Another major threat to human and environmental health in the Bor area is the out-dated processing technology (i.e., classic pyrometallurgical processing) uses sulphur dioxide gas $\left(\mathrm{SO}_{2}\right)$ to produce sulphuric acid $\left(\mathrm{H}_{2} \mathrm{SO}_{4}\right)$ with less than $50 \%$ degree of utilization (Nikolic et al., 2010). This variable was not considered in our study, and as a consequence, future studies should comprehensively examine its impact on native aquatic ecosystems since over 200000 tons of sulphur dioxides are being released to the environment from the Copper Smelter Complex Bor alone (Nikolic et al., 2010).

Heavy metals present in high concentrations are manifest potentially toxic to microorganisms and affect their community structure by reducing their number, diversity, and biochemical activity. At the same time, metal exposure results in the establishment of metalotolerant/resistant microbial populations. Due to selective pressure from the metals in the growth environment, indigenous microorganisms have evolved and developed various mechanisms to resist heavy metal stress and may play a significant role in the restoration of contaminated environments (Rathnayake et al., 2009; Bajkić et al., 2013).

The bacteria can have genes that encode for metal tolerance in the bacterial chromosome, and genes encoding tolerance to metals in the plasmid. Bacteria is capable of ensure the transfer of genetic material between species of plasmids and characters such as resistance to heavy metals can be transferred between related species (Gogartin et al., 2002). The 
bacteria can tolerate heavy metals by controlling the transport in and out of their cells or divide them into cells. Also other mechanisms such as the production of siderophores, are known to detoxify heavy metals in bacteria (Boyd and Rajakaruna, 2013). Substrates with high content of heavy metals represent environments with high levels of metal pollution and provide habitat for bacteria resistant to metal or respective metals. Previus studies have shown that surface waters around mining exploitations contain a high concentration of heavy metals, as well as certain species of bacteria resistant to this kind of contamination, as for example bacteria found in waters contaminated with residues from the uranium mine (Choudhary et al., 2012). Heavy metals can not be degraded, so the only way to remove them from the environment is to use a bioremediation strategy based on the use of microorganisms. Bioremediation is the most effective and least expensive method of treating metal contaminated environments (Wei et al., 2009).

Other studies highlight the possibility to use phytoremediation (hyperaccumulator plants) which in some cases are more efficient than microbial treatment. Decontamination and pollution reduction organic and inorganic at the water column and sediment may be achieved with the aid phytoplanktonului; structure (e.g. Lemna minor, Lemna gibba, Spirodela polyrhiza) and its functions being the decisive factor (Lafabrie et al., 2013; Baudo et al., 2015). At soil level of heavy metal pollution reduction is made using hyperaccumulator plants (Rumex crispus, Poa trivialis, Brassica napus, Allium sativum, Zea mays, Lolium perenne, Polygonum convolvulus, Vicia faba, Sonchus oleraceus, etc.) and green filamentous algae (Lindernia dubia, Chara vulgaris, Cladophora vagabunda, Spirogyra sp., etc.) (Tangahu et al., 2011; Muller et al., 2013; Chibuike and Obiora, 2014).

The concentration of heavy metals and bacterial community dynamics detected in the sediments, indicate the existance of inorganic pollution of aquatic environment due to mining and smelting in the Bor area. Therefore, further studies will be of great importance to identify the potential bio-indicators for heavy metal pollution and new groups of microorganisms capable to tolerate high concentrations of such metals.

Acknowledgements. The present work was funded through the project "Cross-border network for advanced training and research in environmental protection - RoS-Net, Code 464" Romania-Republic of Serbia IPA Cross-border Cooperation Programme. This project is financed by the European Union under the Instrument for Preaccession Assistance (IPA) and co-financed by the partner states in the programme. The authors declare that they have no conflict of interest.

\section{References}

Abrahim G.M.S. and Parker P.J., 2008. Assessment of heavy metal enrichment factors and the degree of contamination in marine sediment from Tamaki Estuary Auckland, New Zealand. Environ. Monitor Assess., 136, 227-238.

Bajkić S., Naranèić T., Đokić L., Đorđević D., Nikodinović-Runić J., Morić I. and Vasiljević B., 2013. Microbial diversity and isolation of multiple metal-tolerant bacteria from surface and underground pits within the copper mining and smelting complex Bor. Arch. Biol. Sci., Belgrade, 65, 375-386.
Baudo R., Foudoulakis M., Arapis G., Perdaen K., Lanneau W., Paxinou A.C.M., Kouvdou S. and Persoone G., 2015. History and sensitivity comparison of the Spirodela polyrhiza microbiotest and Lemna toxicity tests. Knowl. Manag. Aquat. Ecosyst., 416, 23, DOI: $10.1051 / \mathrm{kmae} / 2015019$.

Bouskill N.J., Barker-Finkel J., Galloway T.S., Handy R.D. and Ford T.E., 2010. Temporal bacterial diversity associated with metalcontaminated river sediments. Ecotoxicology, 19, 317-328.

Boyd R.S. and Rajakaruna N., 2013. Heavy Metal Tolerance, Ecology - Oxford Bibliographies, 1-24.

Brankov J., Milijašević D. and Milanovć A., 2012. The assessment of the surface water quality using the water pollution index: a case study of the Timok river (the Danube Rivr Basin), Serbia. Arch. Environ. Protect., 38, 49-61.

Bugarin M., Jonović R., Avramović L., Ljubojev M., Stevanović Z. and Marinković V., 2013. Integrated Treatment of Waste Water and Solid Mining Waste. Journal of Technics Technologies Education Management, 8, 423-429.

Cappucino J.G. and Sherman N., 2008. Nitrification. In Microbiology a Laboratory Manual. International student edition, 7th edition. Addison Wesely Publication, 343-344.

Chibuike G.U. and Obiora S.C., 2014. Heavy Metal Polluted Soils: Effect on Plants and Bioremediation Methods. Appl. Environ. Soil Sci., ID 752708, 12 p., DOI: 10.1155/2014/752708

Choudhary S., Ekramul I., Kazy S.K. and Sar P., 2012. Uranium and other heavy metal resistance and accumulation in bacteria isolated from uranium mine wastes. J. Environ. Sci. Health Part A, 47, 622-637.

Clarke K.R., and Gorley R.N., 2001. Primer v5: User manual/Tutorial. Primer-E, Plymouth.

Domagala Z. and Domka F., 1992. Kinetic model of dissimilatory sulfate reduction. Environ. Prot. Eng., 18, 98.

Dragan-Bularda M., 2000. Microbiologie generala. Lucrari practice. Babež-Bolyai University, Cluj-Napoca, 292 p.

Dragićević S., Novković I., Carević I., Ţivković N. and Tošić R., 2011. Geohazard assessment in the Eastern Serbia. Studii si cercetări de geografie si protecpia mediului, 10, 10-19.

Dunca S., Ailiesei O., Nimitan E. and Stefan M., 2007. Microbiologie aplicata. Demiurg, Iasi, 293 p.

Giannopoulou I. and Panias D., 2008. Differential precipitation of copper and nickel from acidic polymetallic aqueous solutions. Hydrometallurgy, 90, 137-146.

Gillan D.C., Baeyens W., Bechara R., Billon G., Denis K., Grosjean P., Leermakers M., Lesven L., Pede A., Sabbe K. and Gao Y., 2012. Links between bacterial communities in marine sediments and trace metal geochemistry as measured by in situ DET/DGT approaches. Mar. Pollut. Bull., 64, 353-362.

Gogartin J.P., Doolittle W.F. and Lawrence J.G., 2002. Prokaryotic evolution in light of gene transfer. Mol. Biol. Evol., 19, 22262238.

Hammer Ø., Harper D.A.T. and Ryan P.D., 2001. Past: Paleontological Statistics Software Package for Education and Data Analysis. Palaeontol Electron., 4, 4 p.

Jin S., Drever JI. and Colberg P.J., 2007. Effects of copper on sulfate reduction in bacterial consortia enriched from metalcontaminated and uncontaminated sediments. Environ. Toxicol. Chem., 26, 225-30.

Kostanjšek R., Lapanje A., Drobne D., Perović S., Perović A., Zidar P., Strus J., Hollert H. and Karaman G., 2005. Bacterial community structure analyses to asess pollution of water and sediments in the Lake Shkodra/Skadar, Balkan Peninsula. Environ. Sci. Pollut. Res., 12, 361-368. 
Kovačević R., Jovašević-Stojanović M., Tasić V., Milošević N., Petrović N., Stanković S. and Matić-Besarabić S., 2010. Preliminary analysis of levels of arsenic and other metalic elements in $\mathrm{PM}_{10}$ sampled near Copper Smelter Bor (Serbia). Chem. Ind. Chem. Eng. Q., 16, 269-279.

Lafabrie C., Hlaili A.S., Leboulanger C., Tarhouni I., Othman H.B., Mzoughi N., Chouba L. and Pringault O., 2013. Contaminated sediment resuspension induces shifts in phytoplankton structure and function in a eutrophic Mediterranean lagoon. Knowl. Manag. Aquat. Ecosyst., 410, 05, DOI: 10.1051/kmae/2013060.

Li X., Zhu Y., Cavagnaro T.R., Chen M., et al., 2009. Do ammoniaoxidizing archaea respond to soil $\mathrm{Cu}$ contamination similarly asammonia-oxidizing bacteria? Plant and Soil, 324, 209-217.

Liu Y., Zheng Y., Shen J., Zhang L., He J., 2010. Effects of mercury on the activity and community composition of soil ammonia oxidizers. Environ. Sci. Pollut. Res. Int., 17, 1237-1244.

Liu Y., Liu Y., Ding Y., et al., 2014. Abundance, composition and activity of ammonia oxidizer and denitrifier communities in metal polluted rice paddies from South China. PLOS ONE, 9, e102000, DOI: 10.1371/journal.pone.0102000.

Magalhães C.M., Machado A., Matos P., Bordalo A.A., 2011. Impact of copper on the diversity, abundance and transcription of nitrite and nitrous oxide reductase genes in an urban European estuary. FEMS Microbiol Ecol., 77, 274-284.

Marinković V., Obradović L., Bugarin M. and Stojanović G., 2014. The impact of polluted wastewater on water quality of the Bor river and surrounding groundwater. Min. Metall. Eng. Bor, 3, 3336.

Markwiese J.T. and Colberg P.J., 2000, Bacterial reduction of coppercontaminated ferric oxide: copper toxicity and the interaction between fermentative and iron-reducing bacteria. Arch. Environ. Contam. Toxicol., 38, 139-46.

Milijašević D., Milanović A., Brankov J. and Radovanović M., 2011. Water quality assessment of the Borska Reka River using the WPI (water pollution index) method. Arch. Biol. Sci. Belgrade, $63,819-824$.

Muller I., Buisson E., Mouronval J.B. and Mesléard F., 2013. Temporary wetland restoration after rice cultivation: is soil transfer required for aquatic plant colonization? Knowl. Manag. Aquat. Ecosyst., 411, 03, DOI: 10.1051/kmae/2013067.

Muyzer G. and Stams A.J., 2008. The ecology and biotechnology of Sulfate-reducing bacteria. Nat. Rev. Microbiol., 6, 441-454.

Nikolić D., Milošević N., Mihajlović I., Živković Ž., Tasić V., Kovačević R. and Petrović N., 2010, Multicriteria analysis of air pollution with SO2 and PM10 in urban area around the copper smelter in Bor, Serbia. Water Air Soil Pollut., 206, 369-383.

Obradović L., Bugarin M. and Marinković V., 2012. The effect of mine facilities on pollution the surrounding surface waterways, Min. Metall. Eng. Bor, 4, 191-196.

Panias D., 2006. Consequences of environmental issues on sustainability of metal industries in Europe: the case study of Bor. Metalurgija, 12, 239-250.

Petković S., 2009. The trace of roman metallurgy in eastern Serbia. $J$. Min. Metall., 45, 187-196.

Petrovć J., Bugarin N., Bugarin M., Gardć V., Stevanovć Z. and Obradovć L., 2013. Pollution of air, water and soil from industrial products of the exploitation and processing of copper ore in Bor. 17th International Research/Expert Conference Trends in the Development of Machinery and Associated Technology, 277-280.

Pringault O., Viret H. and Duran R., 2010. Influence of microorganisms on the removal of nickel in tropical marine sediments (New Caledonia). Mar. Pollut. Bull., 61, 530-541.

Ruyters S., Mertens J., T'Seyen I., Springael D., Smolders E., 2010, Dynamics of the nitrous oxide reducing community during adaptation to Zn stress in soil. Soil Biol. Biochem., 42, 1581-1587.

Sakadevan K., Zheng H. and Bavor H., 1999. Impact of heavy metals on denitrification in surface wetland sediments receiving wastewater. Water Sci. Technol., 40, 349-355.

Serbula S.M., Antonijevic M.M., Milosevic N.M., Milic S.M. and Ilic A.A., 2010. Concentrations of particulate matter and arsenic in Bor (Serbia). J. Hazard Mater., 181, 43-51.

Serbula S.M., Miljkovic D.D., Kovacevic R.M. and Ilic A.A., 2012. Assessment of airborne heavy metal pollution using plant parts and topsoil. Ecotoxicol. Environ. Saf., 76, 209-214.

Serbula S.M., Kalinovic T.S., Ilic A.A., Kalinovic J.V. and Steharnik M.M., 2013. Assessment of airborne heavy metal pollution using Pinus spp. and Tilia spp. Aerosol. Air Qual. Res., 13, 563-573.

Shafie N.A., Aris A.Z., Zakaria M.P., Haris H., Lim W.Y. and Isa N.M., 2013. Application of geoaccumulation index and enrichment factors on the assessment of heavy metal pollution in the sediments. Environ. Sci. Health A, 48, 182-190.

Simić S., 2004. Changes in structure of the phytoplankton in the barje reservoir (Serbia). Kragujevac J. Sci., 26, 53-64.

Sobolev D. and Begonia M.F.T., 2008. Effects of Heavy Metal Contamination upon Soil Microbes: Lead-induced Changes in General and Denitrifying Microbial Communities as Evidenced by Molecular Markers. Int. J. Environ. Res. Public Health, 5, 450-456.

Tamaki S. and Frankenberger W.T.Jr., 1992. Environmental biochemistry of arsenic. Rev. Environ. Contam. Toxicol., 124, 79-110.

Tangahu B.V., Abdullah S.R.S., Basri H., Idris M., Anuar N. and Mukhlisin M., 2011. A review on heavy metals (As, $\mathrm{Pb}$, and $\mathrm{Hg}$ ) uptake by plants through phytoremediation. Int. J. Chem. Eng., ID 939161, 31 p., DOI: 10.1155/2011/939161.

Thiyagarajan V., Tsoi M.M., Zhang W. and Qian P.Y., 2010. Temporal variation of coastal surface sediment bacterial communities along an environmental pollution gradient. Mar. Environ. Res., 70, 5664.

UNESCO/WHO/UNEP, 1996. Water Quality Assessement-A guide to use of biota, sediments, and water in environmental monitoring. University Press, Cambridge.

Wei G., Fan L., Zhu W., Fu Y., Yu J. and Tang M., 2009. Isolation and characterization of the heavy metal resistant bacteria CCNWRS33-2 isolated from root nodule of Lespedeza cuneata in gold mine tailings in China. J. Hazard. Mater., 162, $50-56$.

Yisa J., Jacob J.O. and Onoyima C.C., 2012. Assessment of toxic levels of some heavy metals in road deposited sedimentts in Suleja, Nigeria. Am. J. Chem., 2, 34-37.

Cite this article as: M.N. Filimon, R. Popescu, F.G. Horhat, O.S. Voia, 2016. Environmental impact of mining activity in Bor area as indicated by the distribution of heavy metals and bacterial population dynamics in sediment. Knowl. Manag. Aquat. Ecosyst., $417,30$. 